Full length article

\title{
A modified ecological footprint method to evaluate environmental impacts of industrial parks
}

\author{
Yupeng Fan $^{\mathrm{a}}$, Qi Qiao ${ }^{\mathrm{a}, *}$, Chaofan Xian ${ }^{\mathrm{b}}$, Yang Xiao ${ }^{\mathrm{b}}$, Lin Fang ${ }^{\mathrm{a}}$

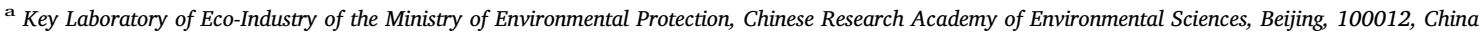 \\ b Research Center for Eco-Environmental Sciences, Chinese Academy of Sciences, Beijing, 100085, China
}

\section{A R T I C L E I N F O}

\section{Keywords:}

Industrial park

Ecological footprint

Ecological capacity

Eco-industrial development

Sustainability

Environmental impact

\begin{abstract}
A B S T R A C T
Industrial parks have been playing a crucial role on driving regional economic development, but also been exerting significant impacts on natural ecosystems due to intensive resource consumption and waste emission. Ecological footprint method is a tool for analyzing the impact of human activities on environment, which has been applied in many fields. Most of the researches applying ecological footprint are conducted on large-scale objects, such as nation and globe. The ecological footprint analysis on the scale of the industrial park, however, is limited. This paper presents a modified ecological footprint accounting model, and applies it to appraise the environmental impact of an industrial park-Hefei economic and technological development area. Results show that the ecological footprint (8.87E + 05 gha (global hectares)) far exceeds the ecological capacity (4.82E + 04 gha), meaning that the ecological footprint is 18.4 times of the ecological capacity in the study park. In addition, the ecological footprint reduction caused by eco-industrial development in the study industrial park is quantified by ecological footprint model. The ecological footprint has been reduced by $15.9 \%$, from $1.06 \mathrm{E}$ + 06 gha to 8.87E + 05 gha, which signifies an obvious environmental performance and economic benefits. Based on this study, the utilization of energy and material could be optimized in industrial park to reduce the influence of industrial activities on natural ecosystem. This paper provides a basis for an industrial park's environmental management and decision making.
\end{abstract}

\section{Introduction}

Among various human activities promoting economic growth in China, industrial parks are themajor contributor. In the past 30 years, China established more than 2000 industrial parks, which accounted for more than $60 \%$ of gross national industrial output value and more than $50 \%$ of GDP (Bao, 2013). In 2014, the GDP growth rate of industrial parks, $29.1 \%$, prominently surpassed that of the national average, 7.4\% (CADZ, 2014). Industrial parks play an important role in driving the regional economy, but it has a huge impact on natural environment due to intensive industrial activities. It is very important for industrial parks' sustainable development to assess the environmental impact caused by resource consumption and waste emissions.

Market prices or other monetary appraisal methods are untrustworthy ways for indicating the long-term viability of ecosystems that provide goods and services such as topsoil evolution, climate-related security, biodiversity, fuel, and feed. The ecological footprint (EF) measures demands for natural resources and pressures on ecosystems (Wackernagel and Rees, 1998). As an effective assessment tool, ecological footprint can measure human's resources throughput and evaluate the actual depletion of natural resources, and thus appraise the gap between humanity's demand and natural services supply (Van Kooten and Bulte, 2000).

The original EF concept, introduced by Rees (1992), is that every individual, process, activity, and region has an impact on the Earth, via resource usage, waste generation and the use of services provided by nature. These impacts can be converted to biologically productive area which can be quantified. Ecological footprint signifies the land area required to maintain present levels of resource consumption and waste discharge by a given population. It provides an intuitive framework for understanding the ecological bottom-line of sustainability, and then stimulates public debate, builds common understanding, and suggests a scheme for action. Ecological footprint makes the sustainability challenge more transparent-decision makers have a physical criterion for rating policy, project or technological options according to their ecological impacts (Wackernagel and Rees, 1997). Ecological footprint is closely related to the concept of ecological carrying capacity, which is the population of a given species that can be supported in a defined

\footnotetext{
* Corresponding author.

E-mail addresses: 531631392@qq.com, qiaoqi@craes.org.cn (Q. Qiao).
} 
habitat without permanently damaging the ecosystem (Catton, 1986; Arrow et al., 1995). If an EF is larger than the corresponding ecological carrying capacity, 'ecological deficit' occurs (Wackernagel and Rees, 1997), indicating the ecological capacity barely supports sustainable development.

$\mathrm{EF}$ analysis has been used to study many systems of different scales, including regions (Wackernagel et al., 2006; Wackernagel and Yount, 1998), nations (Lenzen and Murray,2001; Begum et al., 2009; Wang et al., 2017), and even the whole globe (Galli et al., 2012; Wackernagel et al., 2002), in which the national EF analyses are popular due to data availability. The national scale data needed in EF estimation is easy to get from the international organization such as FAO (Food and Agriculture Organization) or UN (United Nations). Many EF analyses affirmed that most countries with advanced economies were not sustainable (Kitzes et al., 2007; Wackernagel et al., 1999; Wackernagel et al., 2002). Globally speaking, Wackernagel et al. (2002) concluded that the total ecological footprint of human beings in a given time surpassed the regeneration capacity of the Earth's resources. Some EF analysts claimed that if a region's ecological footprint was larger than its ecological carrying capacity, it would impair the regenerative capacity of the local natural assets (Rees and Wackernagel, 2008; Wackernagel et al., 2006). The region therefore must import external resources, and strengthen technological innovation to reduce the consumption of local resources (Opschoor, 2000). In addition, EF is widely applied in various fields. Many scholars studied the aquaculture industry by EF analysis (Gyllenhammar and Håkanson, 2005; Roth et al., 2000; Berg et al., 1996). Gössling et al. (2002) and Castellani and Sala (2012) applied EF analysis to tourism, and both found that ecological footprint was an effective tool in assessing the sustainability of tourism; Wright and Drossman (2002), and Flint (2001) conducted EF analysis on schools respectively, and identified those components which accounted for the large parts of the footprint and thus provided the opportunity for effective management. Through the study of the EF of many products and services consumed in the western economy, Huijbregts et al. (2008) found that the ecological footprint of most of the products was dominated by the non-renewable energy consumption.

Some researchers have applied EF method to the analysis of industrial parks (Liu et al., 2015a; Chen et al., 2013). These researches are however limited and not comprehensive in EF accounting. Compared to other sustainability assessment methods such as LCA or emergy method (Guinée,2002; Liu et al., 2014; Odum, 1996), ecological footprint method is more intuitive and more transparent. Since EF uses a land area (global hectares) to reflect the human impact, people will understand this concept more easily. LCA can analyze the environmental impact but it cannot conduct comparison with the carrying capacity (Guinée, 2002). Emergy method could quantify the resources consumption by a unified physical unit, but it is not directly comparable with local environmental capacity (Chen et al., 2017; Liu et al., 2014). EF method can measure ecological footprint and ecological carrying capacity, and conduct comparison between them.

Promoting eco-industrial development (EID) by the principles of industrial ecology (IE) provides a way to approach sustainable development in industrial park. Industrial ecology is a concept for studying the sustainable development of environmental and economic systems (Chertow, 2000; Chertow, 2007). According to the United Nations Environment Programme (UNEP, 2004), IE is "the systems-oriented study of the physical, chemical, and biological interactions and interrelationships both within industrial systems and between industrial and natural ecological systems." Eco-industrial park (EIP) is one of the important practical forms of IE. Industrial symbiosis (IS), in the form of eco-industrial parks, provides a method to combine local economic development with advantageous environmental outcomes (Chertow and Ehrenfeld, 2012). Gathered according to principles of industrial ecology, the functions of industries in an EIP complemented each other by improving outputs, saving resources and energy, and abating environmental impacts (Yu et al., 2014). The eco-industrial development practices involved physically exchanges between one another of raw material and wastes/by-products and sharing/consolidating/coordinating the management of utilities and infrastructures such as water supply, energy utilization, pollutant emissions, and distributions (Gibbs and Deutz, 2007; Yang and Feng, 2008). Since the success of the Kalundborg industrial symbiosis in Denmark (Jacobsen, 2006), EIPs have emerged around the world (Farel et al., 2016), including Europe (Gibbs and Deutz, 2007), the United States (Gibbs and Deutz, 2005), Australia (Roberts, 2004), Korea (Behera et al., 2012), and China (Zhang et al., 2010; Yu et al., 2015). Chinese EIPs incorporate the principles of industrial symbiosis, such as infrastructure sharing and wastes/byproducts exchange. Also, they adopt varied environmental management tools, including cleaner production and energy audit, to promote eco-industrial development and improve environmental performance (Shi et al., 2012a,b; Tian et al., 2014; Yune et al., 2016; Liu et al., 2015b). In industrial ecology, the industries in a park formed a community and each industry occupied a niche. If the community is symbiotic, the energy and resources they used, products they produced, and the wastes they generated would form an ecological echelon and the resources and energy flowed through from bottom up. The functionalities, benefits, and impacts of the industrial park community therefore should be characterized in terms of flows and balances of energies and resources that were present in different forms and were expressed in different units.

In this study, from an ecosystem perspective, a modified EF accounting method was proposed, as an unbiased and comprehensive tool, to evaluate the sustainability of one industrial park and the performance of eco-industrial development.

Complete EF accounts of an industrial park measure the biologically productive space occupied exclusively to provide all the resources which the industrial park consumes and to assimilate all the wastes the park generates. This study aims to explore the natural impact of the industrial activities at an industrial park based on modified EF analysis. In the following, Section 2 introduces an innovative component EF method which can investigate the whole impact of industrial park. Section 3 describes a case study of a typical industrial park in Hefei. Section 4 calculates the ecological footprint, ecological capacity and ecological deficit of the study park, and discusses EF reduction due to the implementation of eco-industrial development.

\section{Method}

\subsection{Ecological footprint estimation}

The original methodology for calculating ecological footprint, developed at the University of British Columbia, is outlined in earlier publications (see for example Rees (1992) and Wackernagel and Rees (1998)). Ecological footprint accounts express the use of built-up areas, and the consumption of energy and renewable resources-crops, animal products, timber, and fish-in standardized units of biologically productive area, termed global hectares (gha). One global hectare is equal to 1 ha with the average productivity of the 11.4 billion bioproductive ha. Two conversion factors-equivalence factor (see Table 1) and yield factor-convert each of the biologically productive areas from hectares into global hectares. Equivalence factor represents the relative productivity of a particular type of land to the world average productivity of all land. Yield factor accounts for differences between countries in productivity of a given type of land. For this study, the equivalence factors are cited from the work presented by Wackernagel et al. (2004a). The global average productivity is applied in this study so the yield factor is not needed for this ecological footprint calculation.

The conventional EF analysis does not take into account the nonrenewable resources and water resources (Wackernagel et al., 2004b). The non-renewable and water resources, however, are important powers to drive industrial production in the industrial park (Yune et al., 
Table 1

Equivalence factors for different land types.

Source: Wackernagel et al. (2004a).

\begin{tabular}{ll}
\hline Bioproductive area & Global hectares/ha \\
\hline Cropland (overall) & 2.1 \\
Primary & 2.2 \\
Marginal & 1.8 \\
Pasture & 0.5 \\
Forest & 1.4 \\
Fisheries & 0.4 \\
Built-up area & 2.2 \\
Hydropower area & a \\
Fossil Fuels (Forest) & 1.0 \\
\hline
\end{tabular}

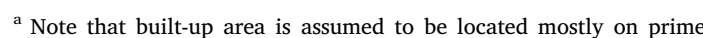
agricultural land. Hence, built-up area has the same equivalence factor.

2016; Wang et al., 2006). Therefore, a modified EF analysis was proposed in this study to count these resources, so as to reflect the real environmental impact of industrial processes in the industrial park.

In the case of industrial park, the ecological footprint of renewable resources and energy $\left(A_{1}\right)$ can be calculated as follows:

$A_{1}=\sum\left(\frac{R_{i}}{N P_{i}} f_{i}+\frac{E_{j}}{E P_{j}} f_{j}\right)$

where $R_{i}$ is the amount of consumption of renewable material $\mathrm{i}$; $E_{j}$ is the amount of consumption of energy j. $N P_{i}$ and $E P_{j}$ are productivities per hectare of the particular land corresponding to material $i$ and energy $j$, respectively; $f_{i}$ is equivalence factor of the land corresponding to renewable material $i, f_{j}$ is equivalence factor of the land corresponding to energy $\mathrm{j}$.

In the conventional EF method, the choice of the account is mainly concerned with the consumption of biological products and energy products. The non-renewable resources producing so much ecological footprints in industrial production should be calculated in this study. Fish land is one of the six main types of production land, which is one kind of ecological footprint account. However, biological production is only one of the functions of water. Water resources have multiple functions which cannot be replaced in the maintenance of the ecological environment and in the process of social life and production. Throughout the research for theory and practice of ecological footprint previously, the estimation of water resources was ignored. Therefore, water resource needs to be considered in the EF calculation. The pollutants discharged into the environment need to occupy a part of biologically productive land, corresponding to a certain ecological footprint, which cannot be ignored. In this case, the EF of various kinds of pollutants, which is ecological productive land occupied to assimilate waste to meet with relevant requirements, is calculated to make the $\mathrm{EF}$ accounting results more reasonable and comprehensive.

The EF $\left(A_{2}\right)$ of the non-renewable resources, water resources, and waste assimilation should be calculated

$A_{2}=\sum\left(N_{m} e_{m}+\frac{Q}{Y_{w}} e_{q}+\frac{\mathrm{W}_{n}}{W A_{n}} f_{n}\right)$

where $N_{m}$ is the amount of consumption of non-renewable resource m, $e_{m}$ is the ecological footprint per unit of resource $\mathrm{m}, Q$ is the amount of water consumption, $Y_{w}$ is the average global production capacity of water resources per hectare. $e_{q}$ is equivalence factor of water. $W_{n}$ is the amount of waste $n, W A_{n}$ is the waste assimilation capacity per hectare of the land used to assimilate waste $n$. $f_{n}$ is equivalence factor of the land used to assimilate waste $n$.

The total ecological footprint of an industrial park can be calculated from Eq. (3)

$A=A_{1}+A_{2}$

\subsection{Ecological capacity accounting}

In the current study, five types of land have been taken into account. In addition to built-up land, arable land, pasture land, and forest, water area is considered as a new added item different from "fish land" in previous studies. No sea area exists in an industrial park. The ecological capacity (EC) of the industrial park is calculated as follows:

$E C=\sum L_{j} E F_{j}$

where $L_{j}$ is area of $\mathrm{j}$-type land, $E F_{j}$ is the corresponding equivalence factor of $j$-type land.

\subsection{Case study park}

\subsubsection{Description and data collection}

Hefei economic and technological development area (HETDA) was chosen for case study. It covers an administrative area of $258 \mathrm{~km}^{2}$ at present, including separate sections for built-up land, forest, pasture land, cropland and water bodies (Nanyan lake, Feicui lake, etc.) (HETDA, 2014). Over the past two decades, HETDA has established 4 pillar industries (home appliances, equipment manufacturing, automobile and parts, fast-moving consumer goods) and 4 emerging industries (electronic information, new materials, bio-pharmaceuticals, industrialized housing). Examples of famous companies include Hitachi, Midea, Haier, Gree, JAC, Navistar, Unilever, Coca-Cola, Unipresident, etc.

The statistical yearbook of HETDA (HETDA, 2014), government report, natural resources and environment statistical yearbook, and environmental reports of environmental protection bureau and key companies within HETDA were collected for extracting useful information and data. 180 survey sheets were sent to enterprises and organizations within HETDA to gather the material/energy consumption information and 153 valid ones were recovered. We reviewed the primary data and validated their authenticity and accuracy through field investigations and in situ observations to ensure the reliabilities and trustworthiness of the data. The year of 2014 is defined as the base year.

\subsubsection{Eco-industrial development}

Since Hefei is a famous tourist city and has several historical heritages, maintaining a clean and pleasant environment in Hefei's largest industrial park (HETDA) is thus beneficial to its economic well-being. Given these regional characteristics, HETDA has a great desire to improve the park's eco-efficiency and environmental quality overall. Therefore HETDA applied for the national title "National demonstration eco-industrial park" (NDEIP) in 2010 and intended to pass the national onsite inspection organized by MEP (Ministry of Environmental Protection), MOC (Ministry of Commerce), and MOST (Ministry of science and technology) in 2015. After several years' eco-industrial development, HETDA has made some achievements. Fig. 1 shows the holistic eco-industrial structure in HETDA. Under the NDEIP project, the wastewater pipelines were extended to $287 \mathrm{~km}$ and the wastewater treatment capacity reached to $8.513 \mathrm{E}+7 \mathrm{t} / \mathrm{yr}$. Several plants have been rejected to settle in HETDA due to large energy consumption and environmental decay. Over 50 coal-burning boilers have been phased out due to their low energy efficiency and high emissions. All the 24 key polluting companies have passed cleaner production audits and adopted over 500 cleaner production options in order to promote the pollution prevention. Jinyuan thermal power plant, as one role model, adopted the wet limestone-gypsum flue gas desulfurization process and the low $\mathrm{NO}_{\mathrm{x}}$ emission combustion technology that conserved energy and reduced emissions (HETDA, 2014). More importantly, in order to propel EID, HETDA determined to promote by-product exchanges among the four main industrial clusters and four emerging industries. Several synergy opportunities have been identified and implemented 




Fig. 1. Ecological industrial structure diagram at HETDA.

through the NDEIP construction efforts. For instance, fly ash and slag produced from Jinyuan thermal power plant become feed stock of building material producers in manufacturing construction material. Another example is that scrap steel and iron generated by local equipment manufacturing were reused as raw materials. From the view of infrastructure sharing, many enterprises used the steam from the local cogeneration power plant thus avoided using their own boilers.

\section{Results and discussion}

\subsection{Ecological footprint and ecological capacity}

Table 2 shows the ecological footprint of components including raw material use, energy consumption, and waste assimilation in the study park. The total ecological footprint of HETDA is 8.87E + 05 gha through summing all input items. The largest EF component was non-renewable resources consumption $(\mathrm{N})$, which accounted for $70.09 \%$ of the total $\mathrm{EF}$ with a value of $6.22 \mathrm{E}+05$ gha; the second and the third largest EF components were energy consumption (E) and renewable resources consumption (R), which were $16.79 \%$ and $7.15 \%$ of the total $\mathrm{EF}$, respectively. Waste assimilation occupied a certain proportion of the total $\mathrm{EF}(\mathrm{W}, 5.98 \%)$.

Steel and iron occupied the largest EF $(5.10 \mathrm{E}+05$ gha) in the nonrenewable resources. While in the renewable resources, the $\mathrm{EF}$ of maize was the largest component $(2.67 \mathrm{E}+04 \mathrm{gha})$. Coal consumption occupied the largest EF among the 8 categories of energy, with a value of $1.33 \mathrm{E}+05$ gha. $\mathrm{NO}_{\mathrm{x}}$ occupied the largest $\mathrm{EF}$ in the waste assimilation with a value of $4.69 \mathrm{E}+04$ gha.

$\mathrm{EF}$ intensity, defined as the ratio of the EF to the economic output, is used to depict the resource consumption intensity. To produce per $10^{4}$ RMB needs to consume 0.144 gha EF of resources at HETDA. The ratio of GDP to EF in the study area is $6.92 \mathrm{E}+04 \mathrm{RMB} /$ gha, which can be regarded as an attempt to show the close relationship between the "land demand" and economic output, as discussed by Farber et al. (2002) concerning the relationship between available resources and economic output.

Table 3 shows how much ecological capacity is available within the study park. According to HETDA (2014), the study park has an area of $258.57 \mathrm{~km}^{2}$, in which the industrial land area is $42.34 \mathrm{~km}^{2}$, built-up land occupies an area of $62.88 \mathrm{~km}^{2}$, arable land area is $74.46 \mathrm{~km}^{2}$, pasture land area achieves $44.68 \mathrm{~km}^{2}$, and forest area occupies $29.78 \mathrm{~km}^{2}$. In addition, HETDA has a water area of $4.43 \mathrm{~km}^{2}$. The land for biodiversity was not taken into account in the study since an industrial park is a special region for industrial agglomeration. Totally the ecological capacity of this industrial park is $4.82 \mathrm{E}+04$ gha.

\subsection{Ecological deficit}

As the ecological footprint and the ecological capacity available within HETDA are both measured in the same unit, they can be compared directly. If the ecological footprint is larger than the available ecological capacity, an 'ecological deficit' occurs. Results show that HETDA requires land appropriation 18.7 times of the actual ecological capacity of itself, and the industrial park has undergone an ecological deficit of $8.39 \mathrm{E}+05$ gha. In general, the EF of industrial activities has far exceeded the carrying capacity at HETDA. The ecological deficit per hectare is 32.94 gha.

Totally, HETDA can (with its own ecological capacity) only supply $5.4 \%$ of its demand based on the current production level. Consequently, the vast majority of resources at HETDA need to be imported from outside. The assimilation of waste produced from the park has a certain $\mathrm{EF}$ of $5.30 \mathrm{E}+04$ gha, which is larger than carrying capacity of this park. The potential for increasing HETDA's total productive area is not great. Thus the only possibilities for increasing HETDA's biocapacity depend on boosting yields on already existing productive areas and optimizing the land use. 
Table 2

Ecological footprint accounting for HETDA, with and without considerations of EID (Eco-industrial development).

\begin{tabular}{|c|c|c|c|c|c|c|c|c|}
\hline \multirow[t]{2}{*}{ Raw materials } & \multirow[t]{2}{*}{ unit } & \multirow{2}{*}{$\begin{array}{l}\text { Amount (unit/ } \\
\text { year) }\end{array}$} & \multirow{2}{*}{$\begin{array}{l}\text { Ecological footprint Per } \\
\text { unit }\end{array}$} & \multirow[t]{2}{*}{ Land productivity } & \multirow[t]{2}{*}{ Land type } & \multirow{2}{*}{$\begin{array}{l}\text { Ecological equivalence } \\
\text { factor }\end{array}$} & \multicolumn{2}{|c|}{ Total ecological footprint } \\
\hline & & & & & & & Without EID & With EID \\
\hline \multicolumn{9}{|l|}{$\begin{array}{c}\text { Non-Renewable } \\
\text { resources }\end{array}$} \\
\hline Steel and iron & t/year & $4.02 \mathrm{E}+05$ & $1.2687 \mathrm{gha} / \mathrm{t}^{1}$ & - & - & - & $5.68 \mathrm{E}+05$ & $5.10 \mathrm{E}+05$ \\
\hline Copper & t/year & $2.18 \mathrm{E}+04$ & $0.165 \mathrm{gha} / \mathrm{kg}^{2}$ & - & - & - & $3.60 \mathrm{E}+03$ & $3.60 \mathrm{E}+03$ \\
\hline Aluminum & t/year & $1.69 \mathrm{E}+04$ & $2.42 \mathrm{gha} / \mathrm{t}^{3}$ & - & - & - & $4.09 \mathrm{E}+04$ & $4.09 \mathrm{E}+04$ \\
\hline Glass & t/year & $3.91 \mathrm{E}+02$ & $0.24 \mathrm{gha} / \mathrm{t}^{3}$ & - & - & - & $9.38 \mathrm{E}+01$ & $9.38 \mathrm{E}+01$ \\
\hline Rubber and plastic & $\mathrm{t} /$ year & $1.43 \mathrm{E}+05$ & $0.41 \mathrm{gha} / \mathrm{t}^{3}$ & - & - & - & $5.86 \mathrm{E}+04$ & $5.86 \mathrm{E}+04$ \\
\hline Resin & t/year & $2.04 \mathrm{E}+04$ & $0.41 \mathrm{gha} / \mathrm{t}^{3}$ & - & - & - & $8.36 \mathrm{E}+03$ & $8.36 \mathrm{E}+03$ \\
\hline Lime & t/year & $6.82 \mathrm{E}+04$ & $0.033 \mathrm{gha} / \mathrm{t}^{2}$ & - & - & - & $2.25 \mathrm{E}+03$ & 0 \\
\hline Cement & $\mathrm{t} /$ year & $2.19 \mathrm{E}+04$ & $0.2109 \mathrm{gha} / \mathrm{t}^{4}$ & - & - & - & $4.62 E+03$ & 0 \\
\hline \multicolumn{9}{|l|}{ Renewable resources } \\
\hline Tea & t/year & $2.14 \mathrm{E}+02$ & - & $566 \mathrm{~kg} / \mathrm{ha}^{5}$ & cropland & $2.2^{6}$ & $8.32 \mathrm{E}+02$ & $8.32 \mathrm{E}+02$ \\
\hline Water & t/year & $1.40 \mathrm{E}+07$ & - & $294,600 \mathrm{~m}^{3} / \mathrm{ha}^{7}$ & water & $5.19^{7}$ & $3.66 \mathrm{E}+02$ & $2.47 \mathrm{E}+02$ \\
\hline Paper & $\mathrm{t} /$ year & $1.25 \mathrm{E}+04$ & - & $1.2777 \mathrm{t} / \mathrm{ha} / \mathrm{yr}^{5}$ & forest & $1.4^{6}$ & $1.37 \mathrm{E}+04$ & $1.37 \mathrm{E}+04$ \\
\hline Sugar & t/year & $1.90 \mathrm{E}+03$ & - & $4893 \mathrm{~kg} / \mathrm{ha}^{5}$ & cropland & $2.2^{6}$ & $8.54 \mathrm{E}+02$ & $8.54 \mathrm{E}+02$ \\
\hline Maize & t/year & $6.75 \mathrm{E}+04$ & - & $5555.7 \mathrm{~kg} / \mathrm{ha}^{5}$ & cropland & $2.2^{6}$ & $2.67 \mathrm{E}+04$ & $2.67 \mathrm{E}+04$ \\
\hline Wheat & $\mathrm{t} /$ year & $4.08 \mathrm{E}+04$ & - & $4762 \mathrm{~kg} / \mathrm{ha}^{5}$ & cropland & $2.2^{6}$ & $1.88 \mathrm{E}+04$ & $1.88 \mathrm{E}+04$ \\
\hline Soybean oil & t/year & $1.17 \mathrm{E}+03$ & - & $1856 \mathrm{~kg} / \mathrm{ha}^{5}$ & cropland & $2.2^{6}$ & $1.39 \mathrm{E}+03$ & $1.39 \mathrm{E}+03$ \\
\hline Rice & t/year & $9.72 \mathrm{E}+01$ & - & $6562.5 \mathrm{~kg} / \mathrm{ha}^{5}$ & cropland & $2.2^{6}$ & $3.26 \mathrm{E}+01$ & $3.26 \mathrm{E}+01$ \\
\hline Vegetable & t/year & $2.71 \mathrm{E}+03$ & - & $18,000 \mathrm{~kg} / \mathrm{ha}^{5}$ & cropland & $2.2^{6}$ & $3.31 E+02$ & $3.31 E+02$ \\
\hline Fruit & t/year & $4.02 \mathrm{E}+03$ & - & $18,000 \mathrm{~kg} / \mathrm{ha}^{5}$ & cropland & $2.2^{6}$ & $4.91 \mathrm{E}+02$ & $4.91 E+02$ \\
\hline \multicolumn{9}{|l|}{ Energy } \\
\hline Coal & $\mathrm{J} /$ year & $7.59 \mathrm{E}+15$ & - & $80 \mathrm{GJ} / \mathrm{ha} / \mathrm{yr}^{8}$ & Fossil fuel land & $1.4^{6}$ & $1.33 \mathrm{E}+05$ & $1.33 \mathrm{E}+05$ \\
\hline Gasoline & J/year & $4.40 \mathrm{E}+13$ & - & $100 \mathrm{GJ} / \mathrm{ha} / \mathrm{yr}^{8}$ & Fossil fuel land & $1.4^{6}$ & $6.16 \mathrm{E}+02$ & $6.16 \mathrm{E}+02$ \\
\hline Diesel fuel & $\mathrm{J} /$ year & $2.02 \mathrm{E}+14$ & - & $100 \mathrm{GJ} / \mathrm{ha} / \mathrm{yr}^{8}$ & Fossil fuel land & $1.4^{6}$ & $2.83 E+03$ & $2.83 \mathrm{E}+03$ \\
\hline Natural gas & $\mathrm{J} /$ year & $1.05 \mathrm{E}+15$ & - & $100 \mathrm{GJ} / \mathrm{ha} / \mathrm{yr}^{8}$ & Fossil fuel land & $1.4^{6}$ & $1.47 \mathrm{E}+04$ & $1.47 \mathrm{E}+04$ \\
\hline Heat & $\mathrm{J} /$ year & $1.29 \mathrm{E}+15$ & - & $1000 \mathrm{GJ} / \mathrm{ha} / \mathrm{yr}^{8}$ & Built-up land & $2.2^{6}$ & $2.84 \mathrm{E}+03$ & $2.84 \mathrm{E}+03$ \\
\hline Liquefied petroleum gas & $\mathrm{J} /$ year & $3.18 \mathrm{E}+13$ & - & $71 \mathrm{GJ} / \mathrm{ha} / \mathrm{yr}^{9}$ & Fossil fuel land & $1.4^{6}$ & $6.27 \mathrm{E}+02$ & $6.27 \mathrm{E}+02$ \\
\hline Kerosene & $\mathrm{J} /$ year & $6.03 E+11$ & - & $93 \mathrm{GJ} / \mathrm{ha} / \mathrm{yr}^{8}$ & Fossil fuel land & $1.4^{6}$ & $9.08 \mathrm{E}+00$ & $9.08 \mathrm{E}+00$ \\
\hline Electricity $^{12}$ & $\mathrm{~J} /$ year & $3.64 \mathrm{E}+14$ & - & $1000 \mathrm{GJ} / \mathrm{ha} / \mathrm{yr}^{8}$ & Built-up land & $2.2^{6}$ & $8.01 \mathrm{E}+02$ & $8.01 E+02$ \\
\hline \multicolumn{9}{|l|}{ Waste } \\
\hline Wastewater & t/year & $7,802,728$ & - & $365 \mathrm{t} / \mathrm{ha}^{10}$ & water & $0.048^{7}$ & $1.67 \mathrm{E}+03$ & $1.03 \mathrm{E}+03$ \\
\hline $\mathrm{SO}_{2}$ & t/year & 321.36 & - & $0.08865 \mathrm{t} / \mathrm{ha}^{10}$ & forest & $1.4^{6}$ & $7.11 \mathrm{E}+03$ & $5.08 \mathrm{E}+03$ \\
\hline $\mathrm{NO}_{\mathrm{x}}$ & $\mathrm{t} /$ year & 978.97 & - & $0.02920 \mathrm{t} / \mathrm{ha}^{11}$ & forest & $1.4^{6}$ & $1.41 \mathrm{E}+05$ & $4.69 \mathrm{E}+04$ \\
\hline Industrial solid waste & t/year & 159,513 & - & $109,100 \mathrm{t} / \mathrm{ha}^{10}$ & cropland & $2.2^{6}$ & $7.41 \mathrm{E}+00$ & $3.22 \mathrm{E}+00$ \\
\hline Living garbage & t/year & 139,200 & - & $109,100 \mathrm{t} / \mathrm{ha}^{10}$ & cropland & $2.2^{6}$ & $2.81 \mathrm{E}+00$ & $2.81 \mathrm{E}+00$ \\
\hline
\end{tabular}

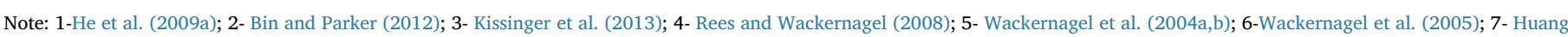


order to avoid double counting, the ecological footprint of electricity should be got from the calculation of Hydro-electricity consumption.

Table 3

Existing ecological capacity within HETDA.

\begin{tabular}{llll}
\hline category & equivalence factor & area $\left(\mathrm{km}^{2}\right)$ & ecological capacity (gha) \\
\hline industrial land & 2.2 & 42.34 & 9314.8 \\
built-up land & 2.2 & 62.88 & 13833.6 \\
arable land & 2.2 & 74.46 & 16381.2 \\
pasture & 0.5 & 44.68 & 2234.0 \\
forest & 1.4 & 29.78 & 4169.2 \\
water & 5.19 & 4.43 & 2299.2 \\
total available & & 258.57 & 48232.0 \\
\end{tabular}

\subsection{Discussion on EID and policy implications}

In recent years, eco-industrial development at HETDA primarily includes cleaner production, infrastructure sharing and by-products (or wastes) exchange. Wastes that can be reused, including wastewater, residual heat, fly ash, slags, steel, and pig iron, are mainly from the cogeneration power plant, equipment manufacturing, auto and electronic enterprises. Main EID activities occur between local cogeneration power plant and other tenant companies. First boiler steam from Jinyuan thermal power plant is being used for fast-moving consumer goods enterprises, construction materials production, and equipment manufacturing, etc., with a certain amount of $1.19 \mathrm{E}+06 \mathrm{t}$ per year. Then fly ash from Jinyuan thermal power plant is being used for cement production, with a total amount of $7.89 \mathrm{E}+04 \mathrm{t}$ per year, which can replace the same amount of cement per year. Finally, the slags from thermal power plant are being used for brick and cement production, with a total amount of $1.42 \mathrm{E}+04 \mathrm{t}$ per year. Other EID activities also include scrap steel and pig iron reuse and occur among local manufacturing, electronic and metallurgical firms, with a total amount of $9.54 \mathrm{E}+04 \mathrm{t}$ per year.

In addition to the practices between enterprises, from the viewpoint of inner-enterprise, enterprises at HETDA make efforts to promote EID projects through technological innovation. Unilever Company developed biomass (straw) combustion boiler technology to replace the natural gas with straw, which conserved energy and improved local environment. Burning straws, in comparison to combusting natural gas, reduced the energy costs by $50 \%$, decreased pollutions associated with open burnings significantly and annual greenhouse gas emissions by $15,000 \mathrm{t}$, and eliminated the needs of landfilling solid wastes (HETDA, 2014). Through technological innovation, Jac-Navistar Diesel Engine Co., Ltd. can recover the iron in the chip liquid which avoids wasting useful materials and reduces the pollutant emissions. Waste recycling is then considered by ecological footprint analysis from the full perspective, so that the holistic picture including saving virgin materials can be presented.

All the EID efforts above can generate significant benefits on saving raw materials and reducing pollutant emissions at HETDA. Therefore the EF of HETDA is reduced due to eco-industrial development (see 
Table 4

The EF changed due to eco-industrial development at HETDA.

\begin{tabular}{lllll}
\hline EF categories & without EID & with EID & $\triangle \mathrm{X}$ & $\mathrm{x} \%$ \\
\hline $\mathrm{R}$ & $6.35 \mathrm{E}+04$ & $6.34 \mathrm{E}+04$ & $1.19 \mathrm{E}+02$ & $0.19 \%$ \\
$\mathrm{~N}$ & $6.86 \mathrm{E}+05$ & $6.22 \mathrm{E}+05$ & $6.49 \mathrm{E}+04$ & $9.45 \%$ \\
$\mathrm{E}$ & $1.55 \mathrm{E}+05$ & $1.49 \mathrm{E}+05$ & $6.52 \mathrm{E}+03$ & $4.19 \%$ \\
$\mathrm{~W}$ & $1.50 \mathrm{E}+05$ & $5.30 \mathrm{E}+04$ & $9.68 \mathrm{E}+04$ & $64.61 \%$ \\
\hline
\end{tabular}

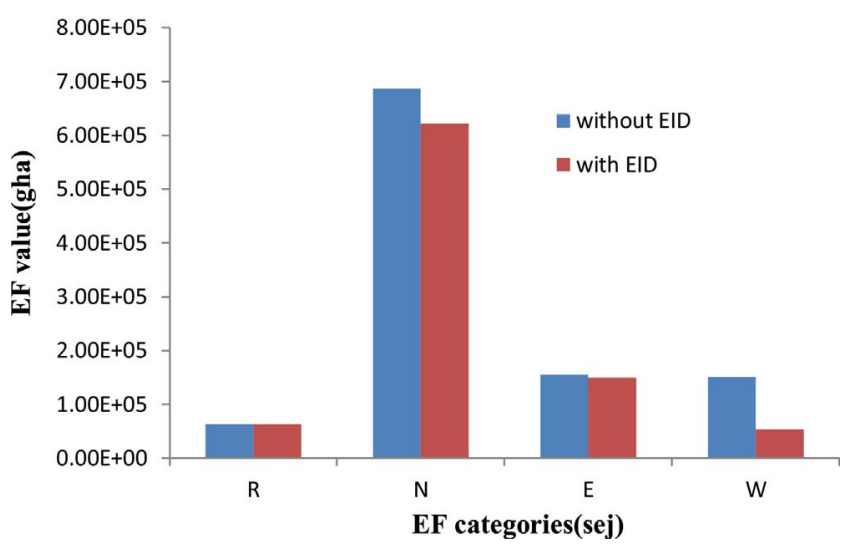

Fig. 2. Comparison of various EF in two sceneries (without or with EID).

Table 4). As shown in Fig. 2, the EF for waste assimilation makes the largest reduction degree from $1.50 \mathrm{E}+05$ gha to $5.30 \mathrm{E}+04$ gha, with a decreasing rate, $64.61 \%$. The non-renewable resources have a total EF of $6.22 \mathrm{E}+05$ gha, reducing $9.45 \%$ of the original EF without EID. EID makes the EF of energy consumption decrease by $4.19 \%$ from $1.55 \mathrm{E}$ +05 gha to $1.49 \mathrm{E}+05$ gha. The $\mathrm{EF}$ of renewable resources decreases from $6.35 \mathrm{E}+04$ gha to $6.34 \mathrm{E}+04$ gha, which is a little change. The reason why the $\mathrm{EF}$ of waste assimilation decreases to the largest degree among the four categories is that a lot of waste was indeed reused for other production processes. In this park, the ecological footprint of nonrenewable inputs, renewable resources consumption, energy use, and pollutants assimilation, can be reduced by $6.49 \mathrm{E}+04$ gha, $1.19 \mathrm{E}$ + 02 gha, $6.52 \mathrm{E}+03$ gha and $9.68 \mathrm{E}+04$ gha, respectively, with the implementation of eco-industrial development. In general, EID reduced the total $\mathrm{EF}$ of the industrial park by $15.9 \%$ from $1.06 \mathrm{E}+06$ gha to $8.87 \mathrm{E}+05$ gha, signifying a great decrease of pressures on environment. The ecological deficit of HETDA decreased by $16.71 \%$ due to ecoindustrial development.

Steel had the largest EF in non-renewable resources, coal made the largest $\mathrm{EF}$ in energy, and the sum of $\mathrm{NO}_{\mathrm{x}}$ and $\mathrm{SO}_{2}$ occupied the largest $\mathrm{EF}$ in waste. Hence, technologies of steel and iron recycling and reuse need to be innovated. The energy structure should be adjusted to reduce the consumption of coal, and increase the use of renewable (green) energy. Last but not least, $\mathrm{NO}_{\mathrm{x}}$ and $\mathrm{SO}_{2}$ should be reduced by innovated technologies of cleaner production and end-of-pipe treatment. In this study, we select the most relevant specific EF from the existing sources. Although we are using the best available data, the results comprise uncertainties and official statistics and EF data sources do not report error boundaries in data, so it is impossible to undertake a formal and rigorous uncertainty analysis.

Policy suggestions have been proposed to improve the sustainability of the industrial park. First, formulating or improving resource depletion taxes and pollution charges can be effective in reducing EF. They provide incentives for firms to save resources and eliminate emissions by adjusting their decision making; second, the industrial park should continue to enhance eco-industrial development including optimizing the land-use pattern and modifying the industrial structure to achieve sustainable development. In addition, compensation of carrying capacity is another important aspect. The most effective strategies for compensating carrying capacity are taking options of renewable electricity generation and plantations. Specifically, options such as the reforestation of already degraded land, the refurbishment of actual irrigation and water supply reservoirs with hydroelectric facilities, and the installation of solar water heaters and solar cells on rooftops are preferred in regard to land disturbance, since these measures have no direct effect on land condition.

\section{Concluding remarks}

Human activities have an impact on the Earth because they consume the products and services of nature (Wackernagel et al., 1999). Industrial parks, consuming large quantities of materials and releasing a great number of pollutants, have a huge impact on natural environment. Study on resources consumption or pollutants emissions embodied in industrial activities will significantly help us to understand how industrial parks interact with their natural environment.

This paper presents the structure of quantifying systematically the ecological footprint based on component frameworks that could be also used in other areas study. Compared to the conventional EF analysis, this method added the accounts of the non-renewable resources, water resource to reflect the real status of an industrial park. The modified method is then applied to the industrial system of HETDA. Research results show that the ecological footprint of HETDA was 8.87E + 05 gha, which was 18.4 times of its ecological capacity, and the ecological deficit achieved $8.39 \mathrm{E}+05$ gha. After the implementation of eco-industrial development, ecological footprint of non-renewable resources, renewable resources, energy and pollutants, was saved by $9.45 \%$, $0.19 \%, 4.19 \%$ and $64.61 \%$, respectively. Overall, eco-industrial development reduced the total ecological footprint of the industrial park by $15.9 \%$ (from $1.06 \mathrm{E}+06$ gha to $8.87 \mathrm{E}+05$ gha), which meant a great decrease of impact on environment. The ecological deficit of this study park was reduced by $16.71 \%$ (1.68E +05 gha) accordingly.

However, there are some limitations in this ecological footprint analysis. Although the principle of EF analysis is fairly simple and intuitional, the data collection process is a time-consuming work and sometimes it is very difficult to complete detailed understanding and adequate collection of the data. Furthermore, although equivalence factors, land productivity and ecological footprint per unit for different items are available in published literature, they are location and process specific and may not fit properly a different investigated case. We collect the most relevant per unit EF and other parameters from the existing sources. There might be numerous opportunities for extending this work from providing greater insights in improving equivalence and yield factors to let them be more fit for relatively small scale, which based on entirely localized data and accurate accounting procedures.

This EF framework offers an intuitive natural capital evaluation for an industrial park with which industrial production demands can be compared with local nature's available supply for the industry use. EF is an accounting tool that can keep track of resources consumption in an ecologically meaningful way. It gives us, therefore, a realistic painting of the industrial park in ecological terms. This is what we need to know to achieve sustainable development, securing quality of industrial production within the means of nature. It requires promoting eco-industrial development, and improving industrial production efficiency while reducing ecological footprint. This study could provide scientific basis and direction for optimizing environmental management in industrial parks.

\section{Acknowledgements}

We are grateful of reviewers' inputs and assistances in revising the manuscript. This work is supported by the National Natural Science Foundation of China (No. 71373248). This study is also supported by State Key Laboratory of Environmental Criteria and Risk Assessment, Chinese Research Academy of Environmental Sciences. 


\section{References}

Arrow, K., Bolin, B., Costanza, R., Dasgupta, P., 1995. Economic growth, carrying capacity, and the environment. Science 268 (5210), 520.

Bao, X., 2013. Exploring a Road to Ecological Transformation for Industrial Parks. Economic Daily. The Economic Daily Press Group, Beijing, China.

Begum, R.A., Pereira, J.J., Jaafar, A.H., Al-Amin, A.Q., 2009. An empirical assessment of ecological footprint calculations for Malaysia. Resour. Conserv. Recycl. 53 (10), 582-587.

Behera, S.K., Kim, J.H., Lee, S.Y., Suh, S., Park, H.S., 2012. Evolution of 'designed' industrial symbiosis networks in the Ulsan Eco-industrial Park: 'research and development into business' as the enabling framework. J. Clean. Prod. 29, 103-112.

Berg, H., Michelsen, P., Troell, M., Folke, C., Kautsky, N., 1996. Managing aquaculture for sustainability in tropical Lake Kariba, Zimbabwe. Ecol. Econ. 18 (2), 141-159.

Bin, G., Parker, P., 2012. Measuring buildings for sustainability: comparing the initial and retrofit ecological footprint of a century home-the REEP house. Appl. Energy 93, $24-32$.

CADZ (China Association of Development Zone), 2014. China Development ZoneStatistics. China finance and Economics Press, Beijing.

Castellani, V., Sala, S., 2012. Ecological footprint and life cycle assessment in the sustainability assessment of tourism activities. Ecol. Indic. 16, 135-147.

Catton, W., 1986. Carrying Capacity and the Limits to Freedom. Social Ecology Session, 1: X1. Eleventh World Congress of Sociology, New Delhi.

Chen, H.S., Chien, L.H., Hsieh, T., 2013. A study of assessment indicators for environmental sustainable development of science parks in Taiwan. Environ. Monit. Assess. 185 (8), 7001-7012.

Chen, W., Liu, W., Geng, Y., Brown, M.T., Gao, C., Wu, R., 2017. Recent progress on emergy research: a bibliometric analysis. Renew. Sustain. Energy Rev. 73, 1051-1060.

Chertow, M., Ehrenfeld, J., 2012. Organizing self-organizing systems. J. Ind. Ecol. 16 (1), 13-27.

Chertow, M.R., 2000. Industrial symbiosis: literature and taxonomy. Annu. Rev. Energy Environ. 25 (1), 313-337.

Chertow, M.R., 2007. Uncovering industrial symbiosis. J. Ind. Ecol. 11 (1), 11-30.

Farber, S.C., Costanza, R., Wilson, M.A., 2002. Economic and ecological concepts for valuing ecosystem services. Ecol. Econ. 41 (3), 375-392.

Farel, R., Charrière, B., Thevenet, C., Yune, J.H., 2016. Sustainable manufacturing through creation and governance of eco-industrial parks. J. Manuf. Sci. Eng. 138 (10), 101003.

Flint, K., 2001. Institutional ecological footprint analysis-a case study of the University of Newcastle, Australia. Int. J. Agric. Sustain. 2 (1), 48-62.

Gössling, S., Hansson, C.B., Hörstmeier, O., Saggel, S., 2002. Ecological footprint analysis as a tool to assess tourism sustainability. Ecol. Econ. 43 (2), 199-211.

Galli, A., Wiedmann, T., Ercin, E., Knoblauch, D., Ewing, B., Giljum, S., 2012. Integrating ecological, carbon and water footprint into a footprint family of indicators: definition and role in tracking human pressure on the planet. Ecol. Indic. 16, 100-112.

Gibbs, D., Deutz, P., 2005. Implementing industrial ecology? Planning for eco-industrial parks in the USA. Geoforum 36 (4), 452-464.

Gibbs, D., Deutz, P., 2007. Reflections on implementing industrial ecology through ecoindustrial park development. J. Clean. Prod. 15 (17), 1683-1695.

Guinée, J.B., 2002. Handbook on life cycle assessment operational guide to the ISO standards. Int. J. Life Cycle Assess. 7 (5), 311-313.

Gyllenhammar, A., Håkanson, L., 2005. Environmental consequence analyses of fish farm emissions related to different scales and exemplified by data from the Baltic-a review. Mar. Environ. Res. 60 (2), 211-243.

HETDA, 2014. Hefei Economic and Technological Development Area Yearbook. The administration committee of Huai'an economic and technological development area (In Chinese).

He, C.L., Wu, J.H., Liu, W.L., 2009a. Calculating the ecological footprint of the iron \& steel industry with a component approach. Acta Scientiae Circumstantiae 29 (12), 2651-2657 (In Chinese).

He, C.L., Wu, J.H., Liu, W.L., 2009b. Calculation method of cement ecological footprint. Acta Ecol. Sin. 29 (7), 3549-3558 (In Chinese).

Huang, L.N., Zhang, W.X., Jiang, C.L., 2008. Ecological footprint method in water resources assessment. Acta Ecol. Sin. 28 (3), 1279-1286 (In Chinese).

Huijbregts, M.A.J., Hellweg, S., Frischknecht, R., Hungerbühler, K., Hendriks, A.J., 2008. Ecological footprint accounting in the life cycle assessment of products. Ecol. Econ. 64 (4), 798-807.

Jacobsen, N.B., 2006. Industrial symbiosis in Kalundborg, Denmark: a quantitative assessment of economic and environmental aspects. J. Ind. Ecol. 10 (1-2), 239-255.

Kissinger, M., Sussman, C., Moore, J., Rees, W.E., 2013. Accounting for the ecological footprint of materials in consumer goods at the urban scale. Sustainability 5 (5), 1960-1973.

Kitzes, J., Peller, A., Goldfiner, S., Wackernagel, M., 2007. Current methods for calculating national ecological footprint accounts. Sci. Environ. Sustain. Soc. 4 (1), 1-9.

Lenzen, M., Murray, S.A., 2001. A modified ecological footprint method and its application to Australia. Ecol. Econ. 37 (2), 229-255

Liu, Z., Geng, Y., Zhang, P., Dong, H.J., Liu, Z.X., 2014. Emergy-based comparative analysis on industrial clusters: economic and technological development zone of Shenyang area, China. Environ. Sci. Pollut. Res. 21 (17), 10243-10253.

Liu, Z., Geng, Y., Wang, F.F., Liu, Z.X., Ma, Z.X., Yu, X.M., Tian, X., Sun, L., He, Q.X.,
Zhang, L.M., 2015a. Emergy-ecological footprint hybrid method analysis of industrial parks using a geographical and regional perspective. Environ. Eng. Sci. 32 (3), 193-202.

Liu, W., Tian, J., Chen, L., Lu, W., Gao, Y., 2015b. Environmental performance analysis of eco-industrial parks in China: a data envelopment analysis approach. J. Ind. Ecol. 19 (6), 1070-1081.

Nowak, D.J., 1994. Air pollution removal by Chicago's urban forest. Chicago's Urban Forest Ecosystem: Results of the Chicago Urban Forest Climate Project. pp. 63-81.

Odum, H.T., 1996. Environmental Accounting: Emergy and Environmental Decision Making. John Wiley and Sons, New York.

Opschoor, H., 2000. The ecological footprint: measuring rod or metaphor. Ecol. Econ. 32 (3), 363-365.

Rees, W., Wackernagel, M., 2008. Urban Ecological Footprints: Why Cities Cannot Be Sustainable_-and Why They Are a Key to Sustainability//Urban Ecology. Springer, US, pp. 537-555.

Rees, W.E., 1992. Ecological footprints and appropriated carrying capacity: what urban economics leaves out. Environ. Urban. 4 (2), 121-130.

Roberts, B.H., 2004. The application of industrial ecology principles and planning guidelines for the development of eco-industrial parks: an Australian case study. J. Clean. Prod. 12 (8), 997-1010.

Roth, E., Rosenthal, H., Burbridge, P., 2000. Discussion of the use of the sustainability index: 'ecological footprint' for aquaculture production. Aquat. Living Resour. 13 (6), 461-469.

Shi, H., Tian, J., Chen, L., 2012a. China's quest for eco-industrial parks, part I. J. Ind. Ecol. $16(1), 8$.

Shi, H., Tian, J., Chen, L., 2012b. China's quest for eco-industrial parks, part II. J. Ind. Ecol. 16 (3), 290.

Tian, J., Liu, W., Lai, B., Li, X., Chen, L., 2014. Study of the performance of eco-industrial park development in China. J. Clean. Prod. 64, 486-494.

UNEP (United Nations Environment Programme), 2004. Division of Technology, Industry, and Economics (UNEP DTIE), Cleaner Production (CP) Activities.

Van Kooten, G.C., Bulte, E.H., 2000. The ecological footprint: useful science or politics. Ecol. Econ. 32 (3), 385-389.

Wackernagel, M., Rees, W.E., 1997. Perceptual and structural barriers to investing in natural capital: economics from an ecological footprint perspective. Ecol. Econ. 20 (1), 3-24.

Wackernagel, M., Rees, W., 1998. Our Ecological Footprint: Reducing Human Impact on the Earth. New Society Publishers, Gabriola Island, BC, Canada.

Wackernagel, M., Yount, J.D., 1998. The ecological footprint: an indicator of progress toward regional sustainability. Environ. Monit. Assess. 51 (1-2), 511-529.

Wackernagel, M., Onisto, L., Bello, P., Linares, A.C., Falfán, I.S.L., Garcıa, J.M., Guerrero, A.I.S., Guerrero, M.G.S., 1999. National natural capital accounting with the ecological footprint concept. Ecol. Econ. 29 (3), 375-390.

Wackernagel, M., Schulz, N.B., Deumling, D., Linares, A.C., Jenkins, M., Kapos, V., Monfreda, C., Loh, J., Myers, N., Norgaard, R., Randers, J., 2002. Tracking the ecological overshoot of the human economy. Proc. Natl. Acad. Sci. U. S. A. 99 (14), 9266-9271.

Wackernagel, M., Monfreda, C., Erb, K.H., Haberl, H., Schulz, N.B., 2004a. Ecological footprint time series of Austria, the Philippines, and South Korea for 1961-1999: comparing the conventional approach to an 'actual land area' approach. Land Use Policy 21 (3), 261-269.

Wackernagel, M., Monfreda, C., Schulz, B.N., Erb Karl-Heinz Haberl, H., Krausmann, F. 2004b. Calculating national and global ecological footprint time series: resolving conceptual challenges. Land Use Policy 21 (3), 271-278.

Wackernagel, M., Monfreda, C., Moran, D., Wermer, P., Goldfinger, S., Deumling, D., Murray, M., 2005. National Footprint and Biocapacity Accounts. The Underlying Calculation Method. Global Footprint Network.

Wackernagel, M., Kitzes, J., Moran, D., Goldfinger, S., Thomas, M., 2006. The ecological footprint of cities and regions: comparing resource availability with resource demand. Environ. Urban. 18 (1), 103-112.

Wang, L., Ni, W., Li, Z., 2006. Emergy evaluation of combined heat and power plant ecoindustrial park (CHP plant EIP). Resour. Conserv. Recycl. 48 (1), 56-70.

Wang, Z., Yang, L., Yin, J., Zhang, B., 2017. Assessment and prediction of environmental sustainability in China based on a modified ecological footprint model. Resour. Conserv. Recycl.. http://dx.doi.org/10.1016/j.resconrec.2017.05.003. in press.

Wang, H.B., 2013. Ecological Footprint Analysis in Beijing Based on Ecological Modified Ecological Footprint Model. Capital University of Economics and Business.

Wright, E.P., Drossman, H., 2002. The ecological footprint of the Colorado College: an examination of sustainability. Environ. Sci. 5 (1), 23.

Yang, S.L., Feng, N.P., 2008. A case study of industrial symbiosis: Nanning Sugar Co., Ltd. in China. Rerour. Conserv. Recycl. 52 (5), 813-820.

Yu, C., Jong, M.D., Dijkema, G.P.J., 2014. Process analysis of eco-industrial park development-the case of Tianjin, China. J. Clean. Prod. 64, 464-477.

Yu, C., Dijkema, G.P., Jong, M., 2015. What makes eco-transformation of industrial parks take off in China? J. Ind. Ecol. 19 (3), 441-456.

Yune, J.H., Tian, J., Liu, W., Chen, L., Descamps-Large, C., 2016. Greening Chinese chemical industrial park by implementing industrial ecology strategies: a case study. Resour. Conserv. Recycl. 112, 54-64.

Zhang, L., Yuan, Z., Bi, J., Zhang, B., Liu, B., 2010. Eco-industrial parks: national pilot practices in China. J. Clean. Prod. 18 (5), 504-509. 